\title{
O ensino confessional e a dimensão religiosa da educação: liberdade e formação humana
}

\author{
The confessional teaching and the religious dimension of education: \\ freedom and human training
}

\begin{abstract}
Resumo: O Supremo Tribunal Federal rejeitou o pedido da Procuradoria Geral da República que considerava inconstitucional o acordo Brasil-Santa Sé que permitia o ensino confessional católico ou de outras confissões nas escolas públicas. Prevaleceu o entendimento da importância do ensino religioso em vista da formação integral da pessoa e de que o ensino religioso, de carater facultativo, é parte integrante da formação básica do cidadão, não sendo suficiente para sua concretização que o fosse de carater secular, confundindo-se com o estudo de história, filosofia ou ciência das religiões. Saindo do complexo e multifacetado embate entre laicidade e confessionalidade, o presente artigo pretende apresentar elementos teóricos para pensar ou repensar a educação confessional, a partir do pensamento de Edith Stein (Santa Teresa Benedita da Cruz/ 1891-1943) que dedicou boa parte e sua vida aos estudos
\end{abstract}

\section{Magna Celi Mendes da Rocha ${ }^{1}$}

Abstract: The Supreme Federal Court has rejected the Attorney General's request, which considered unconstitutional the Brasil-Santa Sé deal, which allowed confessional Catholic education or other kinds of religious denominations in public schools. The prevailing notion is, the importance of religious education regarding the thorough formation of the individual and religious education, as an option, is a component of primary education of every citizen, and would not be sufficiently realized if it were a secular order, being mixed with studies such as History, Philosophy or Religious Sciences. Putting the complex and multifaceted conflict between secularism and confessionalism on the side, the article in hand intends to present theoretical elements to consider or re-consider confessional education arising from the ideas of Edith Stein (Saint Teresa Benedicta of the Cross/1891-1943), who dedi-

1 Doutora e Mestre em Educação: Psicologia da Educação pela PUC-SP. Possui graduação em Pedagogia pela UFPB. Defendeu tese de doutorado (2014) com o título "O sentido de formação em Edith Stein: fundamentos teóricos para uma educação integral" Atualmente, é coordenadora pedagógica e uma das docentes do Curso de Extensão em Ensino Religioso, promovido pela Faculdade de Teologia da PUC-SP em parceria com o Vicariato da Educação e Universidades. 
sobre a formação humana e tinha a convicção de que a formação religiosa era a parte mais importante da formação.

Palavras-chave: Ensino Religioso; confessionalidade; Edith Stein cated most of her life to studies on human development and believed that religious education was the most important part of this development.

Key-words: Religious Education; confessionalism; Edith Stein.

\section{Introdução}

O Supremo Tribunal Federal (STF) julgou improcedente a Ação Direta de Inconstitucionalidade (ADI) 4439/2010 na qual a Procuradoria Geral da República (PGR) questionava o modelo de ensino religioso nas escolas da rede pública de ensino brasileiro. Em sessão plenária final realizada no dia 27 de setembro, por maioria de seis votos a cinco $(6 \times 5)$, os ministros entenderam que o ensino religioso nas escolas públicas brasileiras pode ter natureza confessional, ou seja, vinculado às diversas religiões.

Os principais pedidos da PRG eram os seguintes: declaração de inconstitucionalidade do artigo $11, \S 1{ }^{\circ}$, do acordo Brasil - Santa Sé (Decreto $.^{\circ} 7.107 / 2010$ ) e interpretação do artigo $33, \S \S 1 .^{\circ}$ e $2 .^{\circ}$ da LDB, para se compreender o ensino religioso da constituição federal (artigo $210, \S 1 .^{\circ}$ ), como o ensinamento da história e da doutrina das várias religiões, sob perspectiva laica, isto é, secular.

O acordo em questão, promulgado pelo Decreto 7.107, foi firmado em 11 de fevereiro de 2010 entre o Governo Brasileiro e a Santa Sé, afirma o seguinte:

\footnotetext{
A República Federativa do Brasil, em observância ao direito de liberdade religiosa, da diversidade cultural e da pluralidade confessional do País, respeita a importância do ensino religioso em vista da formação integral da pessoa.

$\S 1^{\circ}$. O ensino religioso, católico e de outras confissões religiosas, de matrícula facultativa, constitui disciplina dos horários normais das escolas públicas de ensino fundamental, assegurado o respeito à diversidade cultural religiosa do Brasil, em con-
} 
formidade com a Constituição e as outras leis vigentes, sem qualquer forma de discriminação. ${ }^{2}$

O artigo da LDB em questão, faz a seguinte afirmação:

Art. 33. O ensino religioso, de matrícula facultativa, é parte integrante da formação básica do cidadão e constitui disciplina dos horários normais das escolas públicas de ensino fundamental, assegurado o respeito à diversidade cultural religiosa do Brasil, vedadas quaisquer formas de proselitismo.

$\S 1^{\circ}$ Os sistemas de ensino regulamentarão os procedimentos para a definição dos conteúdos do ensino religioso e estabelecerão as normas para a habilitação e admissão dos professores.

$\S 2^{\circ}$ Os sistemas de ensino ouvirão entidade civil, constituída pelas diferentes denominações religiosas, para a definição dos conteúdos do ensino religioso. ${ }^{3}$

Como afirmado anteriormente, na ação, a PGR afirmava a inconstitucionalidade desse Acordo, e defendia que o ensino religioso nas escolas públicas não podia ser vinculado a nenhuma religião específica e que fosse proibida a admissão de professores na qualidade de representantes das confissões religiosas. Defendia que tal disciplina, cuja matrícula é facultativa, devia ser voltada para a história e a doutrina das várias religiões, ensinadas sob uma perspectiva exclusivamente neutra, sob o risco de ferir a laicidade do Estado.

Para que fosse assegurada a facultatividade do ensino religioso, segundo o relator, o ministro Luis Roberto Barroso, algumas garantias deveriam ser impostas: não se deveria permitir a matrícula automática na disciplina de ensino religioso; os alunos que optassem por não terem ensino religioso deveriam ter assegurada uma atividade acadêmica no mesmo horário; o ensino religioso deveria ser ministrado em disciplina específica e não transversalmente, e muito menos confessionalmente, ao longo de outras matérias; os alunos deveriam poder se desligar da disciplina quando quiserem.

2 BRASIL, LDB. Lei 9394/96 - Lei de Diretrizes e Bases da Educação Nacional. Disponível em: < www.planalto.gov.br >. Acesso em:10 nov 2017.

3 http://www.planalto.gov.br/ccivil_03/_ato2007-2010/2010/decreto/d7107.htm. 
Dessa forma, o ministro Luís Roberto Barroso propôs a seguinte tese: "O ensino religioso ministrado em escolas públicas deve ser de matrícula efetivamente facultativa e ter caráter não confessional, vedada a admissão de professores na qualidade de representantes das religiões para ministrá-1o"4.

Por maioria, 6 a 5, os ministros do STJ julgaram improcedente o pedido do MPF, declarando, em consequência, a constitucionalidade do acordo Brasil-Santa Sé, para que, à luz do artigo $210, \S 1 .^{\circ}$ da Constituição da República, o ensino religioso seja ministrado com caráter confessional, assim entendido, aulas de catolicismo para os alunos católicos, aulas de protestantismo para os alunos protestantes, aulas de judaísmo para os alunos judeus, de modo que as várias demandas sejam atendidas.

A forma de efetivação dessa decisão é um desafio lançado aos educadores atuais e do futuro, mas prevaleceu o entendimento da importância do ensino religioso em vista da formação integral da pessoa e de que o ensino religioso, de carater facultativo, é parte integrante da formação básica do cidadão, não sendo suficiente para sua concretização que o mesmo fosse de carater secular, confundindo-se com o estudo de história, filosofia ou ciência das religiões.

Votaram pela procedência da inconstitucionalidade os ministros Luís Roberto Barroso (relator), Rosa Weber, Luiz Fux, Marco Aurélio e Celso de Mello. Foram contrários ao pedido do Ministério Público, os ministros Alexandre de Moraes, Edson Fachin, Dias Toffoli, Ricardo Lewandowski, Gilmar Mendes e Cármen Lúcia, sendo esta a última a votar e responsável pelo voto de desempate.

Um dos pedidos era a supressão na Lei de Diretrizes e Bases da qualificação do ensino religioso na escolas públicas como "parte integrante da formação básica do cidadão". "Isso nós consideramos uma impropriedade do ponto de vista pedagógico e político. No entanto, foi mantido e reforçado pelo Supremo." Afirma Luiz Antônio da Cunha, membro do Observatório da Laicidade e também da ação Educa-

\footnotetext{
4 http://www.stf.jus.br/portal/cms/verNoticiaDetalhe.asp?idConteudo=357099 \&caixaBusca $=\mathrm{N}$

5 https://www.cartacapital.com.br/sociedade/decisao-do-stf-sobre-ensinoreligioso-foi-vitoria-dos-catolicos
} 
tiva, organizações que constaram como amicus curiae (partes não envolvidas no processo, mas que fornecem argumento para o julgamento) e defendiam a ADI.

Outras Entidades que atuaram_como amicus curiae a favor do Ministério Público Federal: Grande Loja Maçônica do Estado do Rio de Janeiro (Glmerj), Conectas Direitos Humanos,Ecos-Comunicação em Sexualidade, Comitê Latino-Americano e do Caribe para a Defesa dos Direitos da Mulher (Cladem), Anis-Instituto de Bioética, Direitos Humanos e Gênero e Associação Brasileira de Ateus e Agnósticos.

Consideramos o debate entre laicidade e confessionalidade complexo e multifacetado e, embora reconhecendo a pertinência de tal temática, optamos por não fazê-lo no corpo deste artigo, mas pretendemos apresentar elementos teóricos para pensar ou re-pensar a educação confessional, a partir do pensamento de Edith Stein (Santa Teresa Benedita da Cruz/ 1891-1943) que dedicou boa parte e sua vida aos estudos sobre a formação humana e tinha a convicção de que a formação religiosa era a parte mais importante da formação.

$\mathrm{Na}$ obra de Edith Stein, filósofa, fenomenóloga, educadora, de origem judaica e alemã, convertida à Igreja Católica, o ser humano, em todas as suas dimensões, visto de forma integral e unitária ocupa o centro de todas as suas investigações. Considerando a complexidade humana e apoiando-se na fenomenologia de Husserl, na visão aristotélico-tomista e na doutrina católica, Stein percorre um caminho filosófico, psicológico, antropológico, pedagógico e teológico, chegando a conceber o ser humano como uma unidade indivisível de corpo, psique e espírito, que tem em si um potencial a desenvolver, podendo chegar à sua plena realização ou não. Stein questiona uma educação que não leve em consideração o ser humano completo, mas que se limite a fornecer um acúmulo de informações, visando apenas o desenvolvimento intelectual. Para Stein, uma formação humana autêntica forma o homem de modo integral e o conduz à plena realização de si mesmo, em vista do bem comum, pois cada pessoa que se desenvolve de maneira harmoniosa contribui para o crescimento e desenvolvimento do mundo como um todo.

Para o objetivo do presente artigo, apresentaremos as contribuições de Edith Stein, sobretudo no tocante à formação humana, ao pa- 
pel da liberdade no processo de formação e a importância da relação entre os sujeitos como elemento formativo, com ênfase na dimensão religiosa da educação.

Stein afirmava que "o correto conhecimento das criaturas e o tratamento dado a elas só se tornam possíveis a partir de uma relação correta com o Criador" Tinha a convicção de que a parte mais importante da formação era a formação religiosa, que significava ter uma fé viva em Deus. Para que essa vivência fosse real e autêntica não poderia ser imposta sob nenhum pretexto. $\mathrm{O}$ debate atual sobre o proselitismo religioso pode ser pensado a partir das considerações da autora sobre a liberdade, parte indispensável do processo formativo. Antes, porém, de entrarmos nessa questão vejamos as colocações da autora sobre o ideal de formação que movia seu o desejo de uma profunda reforma educacional.

\section{Edith Stein e o ideal de formação}

Stein defendia uma reforma no sistema educacional alemão, que considerava estar em crise há décadas. Procurando a causa da crise, ela o encontra no conceito de formação em que o sistema educacional estava baseado, que ela considerava falho.

Stein considerava falho, sobretudo, o ideal de formação a ser alcançado, do que chamava "escola antiga": a busca de um saber enciclopédico. Essa escola é "essencialmente uma filha do Iluminismo"?.

O ideal de formação a ser alcançado era de um saber enciclopédico que devia ser o mais completo possível. Pressupunhase que a alma não passava de uma tabula rasa em que deveria ser gravado o máximo, seja pela assimilação racional seja pela inserção na memória ${ }^{8}$.

Falando sobre um novo plano de formação, afirma:

6 E. STEIN, A mulher: Sua missão segundo a natureza e a graça. Tradução Alfred

J. Keller. EDUSC, Bauru, 1999, p.146

7 E. STEIN, A mulher, p.136.

8 E. STEIN, A mulher, p.136. 
Seria necessário desfazer-se completamente da ideia de que a escola deve transmitir um extrato compendioso de todas as áreas do saber de nosso tempo. Mais vale a tentativa de educar pessoas que sejam suficientemente inteligentes e esforçadas para serem capazes de apropriar-se de qualquer matéria que venha a ser importante para ela ${ }^{9}$.

A autora considera a formação como algo mais complexo, que vai além da posse de informações e conhecimentos. Para ela, a "formação e educação devem colher o ser humano na sua totalidade de corpo vivente e alma" 10

Stein considera ainda que "a formação é algo muito mais intrincado, mais misterioso e menos sujeito ao arbítrio que sonhava o Iluminismo. Como não contasse com os fatores de formação essenciais, seu sistema estava destinado ao fracasso." 11

Como a formação e a educação devem colher o ser humano em sua totalidade de corpo vivente e alma, ela considera que, para isso, é importante conhecer a estrutura, as funções e as leis de desenvolvimento do corpo humano "para saber o que é mais útil ou danoso para o desenvolvimento conforme a sua natureza. É igualmente importante conhecer as leis gerais da vida da alma humana para levar em conta no trabalho educativo." ${ }^{2}$ Reconhece também a importância do conhecimento das massas humanas, dos povos, raças etc., pois "é tarefa do educador formar não só como indivíduo, mas também como parte do todo." 13

Stein defende que a compreensão do ser humano individual se dê mediante as ciências do espírito. Assim reivindica:

A antropologia, que exigimos como fundamento para a pedagogia, deverá ser uma antropologia filosófica, que precisará, permanecendo em relação viva com a inteira problemática filosófica, estudar a estrutura do ser humano e sua inserção nas

9 E. STEIN, A mulher, p.145

10 E. STEIN, La strutura della persona humana. Tradução de M. D'Ambra. Città Nuova, Roma, 2000. Título original: Der Aufbau der menschlichen Person, original publicado em 1932/33), p. 55

11 E. STEIN, A mulher, p.139

12 E. STEIN, La strutura, p.55

13 E. STEIN, La strutura, p.55 
formas e nas regiões do ser às quais pertence. Deverá também responder à pergunta sobre o porquê diferentes ciências do espírito estudam o ser humano segundo métodos totalmente diferentes. O sentido e a legitimidade de tais procedimentos devem ser compreensíveis a partir do pertencimento do ser humano aos diferentes âmbitos da realidade que temos indicado com os nomes "natureza" e "espírito.".14

Considera também necessária uma antropologia que integre a teologia e a filosofia. Aliás, Stein defende que o conhecimento teológico é irrenunciável para a pedagogia. Considera São Tomás de Aquino um grande expoente nessa questão, pois no seu pensamento a antropologia assume uma posição central, uma vez que, para ele, o ser humano é um microcosmo que unifica em si todos os reinos do mundo criado. A relação com Deus também assume papel central:

Uma doutrina geral do ser humano não pode limitar-se ao ser criado, mas deve levar em consideração a diferença entre o ser criado e o ser incriado e a relação que ocorre entre eles. Portanto, seria incompleta e inadequada, como fundamento da pedagogia, uma antropologia que não levasse em consideração a relação do ser humano com Deus. ${ }^{15}$

Utilizando o método fenomenológico e a filosofia aristotélicotomista Stein concebe o ser humano como uma estrutura complexa, constituída de corpo, psique e espírito, que se manifesta de forma dinâmica, constituindo um ser unitário. Este ser humano tem a possibilidade de ser livre e consciente de si mesmo e de modificar-se por meio das relações intersubjetivas com os outros seres humanos.

Edith Stein opta pela visão cristã como fundamento para a educação. Além de São Tomás, os autores que mais a influenciaram foram Santo Agostinho e Santa Teresa de Ávila, além das Escrituras e da doutrina católica. Utiliza ainda todo o seu repertório intelectual filosófico, psicológico, pois não desconsidera nenhum tipo de conhecimento.

\footnotetext{
14 E. STEIN, La strutura, p. 62-63.

15 E. STEIN, La strutura, p.63
} 
As ciências (psicologia, antropologia, sociologia) nos oferecem importantes instrumentos para o conhecimento da natureza humana, também para aquela dos jovens. Todavia, elas podem aproximar-se da peculiaridade individual só através de um vivo contato interior; o ato próprio de compreender, que sabe como interpretar a linguagem da alma nas suas diversas formas expressivas (olhar, expressão facial e gestual, palavra e escrita, ação prática e criativa) pode penetrar no profundo. A via para ele é livre, porém, só se a alma se exprime sem impedimentos e se o processo original de desenvolvimento e formação a partir do interior para o exterior não é interrompido. ${ }^{16}$

Ressalta sempre a necessidade de que o conhecimento capte a individualidade das pessoas, pois acredita que "não se podem educar os homens para uma mesma finalidade, segundo um esquema geral. Dar espaço à especificidade da criança é um meio essencial para individuar a orientação interior ao fim." 17

Sberga ${ }^{18}$ lembra que, para Stein, a identidade está no mais profundo da pessoa, na sua interioridade mais central, lá onde não pode ser confundida com ninguém. Lá é pessoa singular.

Esta é uma marca de toda a obra pedagógica de Edith Stein: buscar colher o ser humano em sua individualidade, de forma mais viva e próxima possível, sem aprisioná-lo em esquemas fechados, mas também sem desconsiderar nenhum conhecimento científico para melhor compreendê-lo.

A formação não é uma posse externa de conhecimentos e, sim, a forma que a personalidade humana assume sob a influência de múltiplas forças vindas de fora, ou então o processo dessa moldagem. O material a ser moldado é constituído de um lado pelas aptidões físicas e psíquicas com que o ser humano nasce, pelo material que lhe é constantemente acrescentado de fora e que deve ser assimilado pelo organismo. O cor-

16 E. STEIN, La strutura, p. 51

17 E. STEIN, La strutura, p.52

18 A. A. SBERGA. e M. MASSIMI. A formação da pessoa em Edith Stein: contribuição para a construção de itinerários educativos para crianças, adolescents e jovens. (Tese). Doutorado em Psicologia. Universidade de São Paulo, Ribeirão Preto, 2013. 
po retira esse material do mundo físico, a alma do ambiente espiritual, do mundo das pessoas e dos bens de que deve alimentar-se. $^{19}$

Todo trabalho educativo, em Stein, visa formar o ser humano à plena realização de si mesmo, num processo que acontece de dentro para fora, como atualização de suas potencialidades, ainda que essa plenitude que cada ser humano é chamado a realizar só seja realmente conhecido por Deus, que criou e conhece em profundidade toda a sua criação:

O verdadeiro educador é Deus, o único a conhecer cada homem singular em profundidade, a ter diante dos olhos o fim de cada um e a saber de quais meios tem necessidade para conduzi-lo ao fim. Os educadores humanos são só instrumentos nas mãos de Deus. ${ }^{20}$

Essa afirmação não pode ser interpretada como uma desvalorização do trabalho do educador, que passa a ser visto como "instrumento nas mãos de Deus". Tal premissa é uma grande responsabilidade diante do mistério e da dignidade que se esconde em cada ser humano, independente de condição social, racial, sexual ou cultural. Para Stein, todo ser humano traz em si uma marca da eternidade e anseia por ela. Uma educação que vise apenas o imediato, o terreno, o provisório, não corresponde ao desejo mais profundo dos seres humanos. Não contribui para que cada um realize seu próprio caminho, sua própria via, mas ao contrário, busca uma padronização ou uma competitividade na qual os seres humanos não se reconhecem mais como irmãos, como vindos de uma mesma raiz.

Por isso, Stein considera que o logos eterno é o fundamento ontológico da unidade entre os seres humanos e é isto que faz a educação sensata e possível. Compreende ainda que existe uma ligação objetiva entre humanidade e educação: "A humanidade é uma grande

\footnotetext{
19 E. STEIN, A mulher, p.137

20 E. STEIN, La strutura, p.50
} 
totalidade, deriva de uma raiz, é orientada a um propósito, e tende a um destino." ${ }^{21}$ (1932-33/2000, p. 53).

O Catecismo da Igreja Católica, algumas décadas depois, de acordo com toda a Tradição, assim expressa essa realidade:

Criados à imagem de Deus único, dotados de uma mesma alma racional, todos os homens têm a mesma natureza e a mesma origem. Resgatados pelo sacrifício de Cristo, todos são convidados a participar da mesma felicidade divina; todos gozam, portanto, de igual dignidade.(...) qualquer forma de discriminação nos direitos fundamentais da pessoa, seja (essa discriminação) social ou cultural, ou que se fundamente no sexo, na raça, na cor, na condição social, na língua ou na religião deve ser superada e eliminada, porque contraria ao plano de Deus. $^{22}$

Posto isso, passemos para importância da compreensão da liberdade humana no processo formativo.

\section{O papel da liberdade no processo formativo}

Para Stein, no ser humano, o material a ser formado não é uma material inerte, como argila na mão do artista ou rocha que sofre a ação das intempéries, mas uma raiz viva em formação que, semelhante a uma planta, possui em si mesma uma força invisível, uma força germinativa que tende a uma determinada direção, que amadurece a partir desse germe, até assumir uma personalidade madura e bem desenvolvida, com características individuais claramente definidas.

O conhecer e o querer são atos livres e, também, a entrega aos movimentos, inicialmente espontâneos, do ânimo ou sua recusa, estão ligados à liberdade. Dessa maneira, o ser humano, consciente de sua liberdade, não fica entregue às forças formadoras externas como se fosse uma matéria passiva, pois ele é capaz de abandonar- se a elas ou de recusá-las, ele pode procurar as chances de formação ou po-

21 E. STEIN, La strutura, p.53

22 CATECISMO DA IGREJA CATÓLICA, 4.ed, Vozes, Petrópolos, 1993, p,512 
de evitá-las. De modo que a iniciativa livre, própria, também faz parte dos fatores que participam da formação da alma. $^{23}$

Somente considerando esse aspecto da liberdade de abertura ou fechamento como uma peculiaridade da condição espiritual humana é possível compreender o que Stein considera autonomia e autoeducação. Stein adverte que não se deve entender autoformação como uma formação que depende só do formando que se forma a "si mesmo", independente dos demais, mas no sentido de um processo que compromete a pessoa inteira, e ela própria coloca em ação as forças, sem, no entanto, excluir a participação de outras pessoas nesse processo.

A natureza espiritual do homem - razão e liberdade - exige a espiritualidade do ato pedagógico, isto é, uma ação comum do educador e estudante que leva em conta o crescimento gradual da espiritualidade, em que a atividade de orientar do educador deixe sempre mais espaço à atividade própria do estudante, para conduzi-lo, enfim, à completa autonomia e à autoeducação. ${ }^{24}$

Como afirmamos anteriormente, o intelecto é o órgão responsável pela abertura do mundo à alma. Ele é, ao mesmo tempo, ativo e passivo. Ativo na medida em que elabora a própria riqueza intelectual, pelo instrumento da vontade. Passiva na medida em que recebe algo de fora, mas não o torna próprio.

Stein afirma que, de certo modo, está em nossas mãos o se e o como queremos deixar trabalhar o nosso intelecto e, consequentemente, quanto queremos ampliar nosso mundo espiritual, o que queremos receber dos elementos de formação. Diz ainda:

As forças formadoras do ambiente espiritual, as mãos humanas formadoras são condicionadas não apenas pela formação primária de dentro, elas se veem confrontadas com mais uma força formadora interna. A criança é entregue às mãos dos formadores humanos. $\mathrm{O}$ adolescente que desperta para a liberdade do espírito é entregue a si próprio. Graças ao livre

\footnotetext{
23 E. STEIN, A mulher, p.118

24 E. STEIN, La strutura, p.50
} 
arbitrio, ele mesmo pode trabalhar em sua formação, pode acionar livremente suas forças e cuidar de seu desenvolvimentos, pode abrir-se às influências formadoras ou recusálas. $^{25}$

Em relação à criança, Stein acredita que, desde o nascimento, esta já está imersa em um mundo repleto de pessoas, de bens espirituais, dos quais recebe vida. Os desenvolvimentos psíquico e espiritual acontecem juntos. No entanto, no início de sua existência, o ser humano não dispõe do uso da razão e da liberdade. Desse modo, até que disponha desse recurso, outros precisam trabalhar em sua formação. Mais tarde, a formação de si mesmo e o trabalho formativo dos outros precisam complementar-se mutuamente, sem, contudo, restringir ou dispensar a livre iniciativa de cada um:

A responsabilidade solidária com a qual a humanidade foi criada e o fato de o indivíduo fazer parte de uma unidade abrangente e de comunidades concretas em que essa é subdividida, fazem com que outros continuem responsáveis pelo ser humano e sua formação mesmo depois de já ter despertado para o uso da razão e da liberdade. ${ }^{26}$

Mesmo em se tratando de crianças, que não têm ainda o uso pleno da razão e da liberdade, Stein não admite uma maneira brusca de ter acesso a sua interioridade, mas defende o respeito e a conquista da confiança para que haja uma livre colaboração.

Para que essa livre colaboração ocorra por parte do educando, Stein considera que "o educador tem necessidade de conhecer a alma da criança; porém, só pode abri-lo o amor e um respeitoso temor que não tenta forçar o que é fechado.",27

Consciente dos limites da formação externa Stein admite que:

Todo o trabalho de formação humano só pode trazer o material e oferecê-lo convenientemente "preparado", só pode ir à frente e "mostrar como se faz" para estimular a própria ativi-

\footnotetext{
25 E. STEIN, $A$ mulher, p.138

26 E. STEIN, $A$ mulher, p.228

27 E. STEIN, La strutura, p.51
} 
dade; mas ele não pode obrigar à aceitação e imitação. A natureza restringe o trabalho de formação próprio, a natureza e a liberdade do formando limitam o trabalho de formação alheio $^{28}$.

Para Stein o único formador para o qual não existem esses limites é Deus, que pode, se quiser, intervir na natureza humana, alterando-lhe o curso natural e tornando possível o que é impossível.

Quanto aos formadores humanos ela está convicta dos limites. Afirma que nem os melhores educadores nem as melhores instituições podem garantir o sucesso da tarefa formativa. Só podem fazer tudo o que é humanamente possível, considerando que o trabalho humano de formação é apenas um dos fatores que intervêm no processo. Os outros fatores, ainda que identificados, não podem garantir uma segurança absoluta quanto ao sucesso da formação. Diz ainda que o trabalho de formação costuma ser encerrado antes que o processo de formação esteja concluído.

Já pode ser considerado um grande sucesso quando o educando está disposto a prosseguir por conta própria na direção proposta. Mas, mesmo assim, nunca se pode ter certeza de que essa direção seja mantida quando as circunstâncias da vida levam ao despertar de impulsos naturais contrários. ${ }^{29}$

\section{Relação entre sujeitos como elemento formativo}

Tomando o pensamento de Stein como referência de uma proposta educativa, em uma perspectiva fenomenológica, Pezzella ${ }^{30}$ considera que refletir sobre a formação é, em primeiro lugar, levar em consideração a relação educativa. Relação esta que não é unidirecional, do educador ao educando ou vice versa, mas é sempre de reciprocidade; é um contínuo movimento de "sujeito a sujeito", no qual o outro não pode mais ser definido ou pensado como objeto, sequer

${ }^{28}$ E. STEIN, $A$ mulher, p. 118

${ }^{29}$ E. STEIN, A mulher, p. 127

${ }^{30}$ A. M. PEZZELA, Lineamenti di filosofia dell'educazione- per una prospettiva fenomenologica dell'evento educativo, Lateran University Press, Vaticano, 2007. 
teoricamente; caso contrário, existe o risco de perder uma relação que desejava definir-se como autenticamente formativa.

A relação sujeito a sujeito é um diferencial em relação ao reino animal. "Somente em relação aos seres humanos podemos falar em formação, educação e não de reprodução ou adestramento, como nos animais." 31

Stein dá grande ênfase a essa questão e insiste em um relacionamento mais vivo e próximo possível, não baseado apenas em um conhecimento teórico ou superficial da alma humana, baseada no conhecimento de tipificações humanas, mas sempre aberta para a relação que acontece no aqui e no agora, pois, como afirma Pezzella, "a relação educativa é sempre um evento situado no aqui e no agora, no interior de um momento histórico preciso, cultural, social".

Stein considerava que as tipificações tinham um valor prático para que professores e educadores aguçassem o olhar sobre o material humano que tinham diante de si, mas era preciso precaver-se contra uma classificação esquematizantes num rígido sistema de tipos, para não ser injusto com os indivíduos: "Além disso, a tipificação nos lembra que existe uma grande variedade de tipos humanos, de modo que nem todos se prestam a tudo e nem todos podem ser formados para tudo, que deve haver uma diferenciação de metas, meios e métodos." 32

O risco que Stein observava no excesso da utilização de tipos humanos como referencial da ação pedagógica, é que se chega sempre ao desconhecimento do indivíduo. Haveria também "uma perigosa interrupção da unidade do ato pedagógico"33 se em vez de o educador orientar-se diretamente ao aluno à sua frente, fosse orientado apenas por tipos humanos. Stein acredita que o aluno é capaz de perceber quando não é levado em consideração como indivíduo único e irrepetível, e essa atitude do professor é suficiente para seu fechamento, rompendo, assim, a possibilidade de uma autêntica relação pedagógica.

\footnotetext{
${ }^{31}$ A. M. PEZZELA, Lineamenti, p. 43

${ }^{32}$ E. STEIN, A mulher, p.205

${ }^{33}$ E. STEIN, La strutura, p.56
} 
Edith Stein, ainda referindo-se às exigências da relação professor-aluno, enfatiza a importância da coerência ou do testemunho entre o que se ensina e o que se vive. Referindo-se ao ensino moral, assim afirma:

Quando o ensino de tal gênero é aprendido de maneira viva, conduz ao juízo sobre o comportamento próprio e dos outros. Disto deve levar em conta o professor e quando sua conduta prática não está conforme o conteúdo de seu ensinamento, é inevitável que as crianças cheguem à conclusão que ele não crê no que diz ou que não pode ou não deseja fazer o que indica como obrigatório. ${ }^{34}$

Diante de tantas exigências, o professor, que também é um ser humano limitado, não poderá corresponder a tudo o que sua função lhe atribui, se diante de si não tiver um referencial seguro, se não tiver uma imagem na qual possa espelhar- se para medir a si mesmo e aos outros. Stein não teme considerar que nenhuma imagem humana corresponde a uma autêntica humanidade, à qual todos ansiamos.

A imagem de Cristo, que Stein, após sua conversão acolheu como Deus feito homem, é apresentada como modelo de ser humano, através do qual é possível medir objetivamente a nós mesmos e aos outros. Essa imagem deve ser assumida por todos que desejarem um referencial seguro, para que se faça força íntima e plasme o ser humano desde seu íntimo:

Quanto mais essa imagem de Deus penetrar em nós, quanto mais despertar o nosso amor, tanto mais sensíveis nos tornamos a qualquer tipo de desvio dele dentro de nós e nos outros: abrem-se os nossos olhos para o verdadeiro conhecimento humano, sem qualquer retoque [...] Quem olha para Ele e se orienta por Ele está com os olhos fixos em Deus, protótipo de toda personalidade e síntese de todos os valores. ${ }^{35}$

Facultar à criança o acesso a Deus é, portanto, a missão principal do processo formativo, pois abrindo-se a Deus, a alma está aberta

\footnotetext{
34 E. STEIN, La strutura, p.221

35 E. STEIN, A mulher, p.286-287
} 
a "toda plenitude do mundo espiritual sobre-humano e, com ele, uma quantidade inesgotável de material formador que nela podem entrar para construí-la e transformá-la."36

Essa tarefa, no entanto, só pode ser realizada por pessoas que sejam elas mesmas pontos de apoio e referência viva de abertura a Deus e aos outros, indistintamente, "[...] se a alma se forma desse modo, se tudo nela está no seu lugar, então nela há quietude, claridade e paz, então está 'harmonicamente formada.." ${ }^{37}$

Uma pessoa bem formada se reconhece em suas possibilidades e potencialidades, mas também em suas necessidades e limites. É ainda uma pessoa que desenvolve a humildade de reconhecer que não se basta, mas que precisa da vida em comum para desenvolver-se e precisa ainda do auxílio da Graça Divina, pois sabe que em Deus está o seu princípio e seu fim.

Qual é a grande enfermidade de nosso tempo e de nosso povo? Na grande maioria das pessoas é a desintegração interna, a falta total de conviç̧ões e princípios firmes, à deriva sem direção e, por causa da insatisfação com esse tipo de existência, a busca de entorpecimento em novos prazeres cada vez mais sofisticadas. [...] o remédio contra a doença de nosso tempo são seres humanos plenos [...]: fincados no chão da eternidade não se deixam abalar em suas convicções e em seu agir por opiniões, asneiras e vícios da moda que grassam à sua volta. Cada uma dessas pessoas é como uma coluna firme em que muitos podem agarrar-se para voltar a sentir, por seu meio, o chão firme debaixo dos pés. ${ }^{38}$ (grifo nosso.)

O papa João Paulo II, retomando seus antecessores e o Concílio Vaticano II afirma:

Quero exprimir vigorosamente a convicção de que o homem é capaz de alcançar uma visão unitária e orgânica do saber. Essa é uma das tarefas que o pensamento cristão de-

36 E. STEIN, A mulher, p.147

37 E.STEIN, Sobre el concepto de formaciòn. In STEIN, E... Obras completas IV: escritos antropológicos y pedagógicos. Tradução de F.J. Sancho e cols., Monte Carmelo, Espanha, 2003a, p. 177-194. (Publicação original de 1930), p. 187

38 E. STEIN, A mulher, p.287 
verá assumir durante o próximo milênio da era cristã. A subdivisão do saber, enquanto comporta uma visão parcial da verdade com a consequente fragmentação do seu sentido, impede a unidade do homem de hoje. (2006, p. 114)

Na mesma encíclica, apresenta Edith Stein, ao lado de outros pensadores como Jonh Henry Newman, Antônio Rosmini, Jacques Maritain, entre outros, como "exemplos significativos de um caminho de pesquisa filosófica que tirou notáveis vantagens de sua confrontação com os dados da fé. ${ }^{39}$,

\section{Considerações finais}

O recente julgamento do TSJ reacendeu o debate sobre a laicidade do Estado e o Ensino Religioso confessional em escolas públicas. Alguns defendiam, inclusive, a supressão da disciplina do currículo, por não considerar que um conhecimento desta natureza seja necessário para a formação. Outros defendiam ser necessário um ensino neutro, voltada para o ensino da história das religiões, sendo proibida a admissão de professores na qualidade de representantes das confissões religiosas.

Reconhecendo a complexidade da temática e as sombras que envolvem as posições pró e contra o ensino confessional em escolas públicas, apresentamos a visão educativa de Edith Stein por acreditar que possa lançar luzes à discussão, sobretudo no tocante à sua concepção de formação humana.

Para Edith Stein toda prática educativa é guiada por uma visão cosmológica e antropológica, que deve ser explicitada. Não existe, portanto, possibilidade de uma neutralidade absoluta. Dialoga com as principais concepções antropológicas de seu tempo e encontra na visão de homem cristã, sobretudo a católica, um fundamento seguro.

Considera necessária uma antropologia que integre a teologia e a filosofia. Aliás, Stein defende que o conhecimento teológico é irrenunciável para a pedagogia. Considera São Tomás de Aquino um grande expoente nessa questão, pois em seu pensamento a antropolo-

39 JOÃO PAULO II. Carta Encíclica Fides et ratio. 9 ed, Paulinas, São Paulo, 2006, p. 99. 
gia assume uma posição central, uma vez que, para ele, o ser humano é um microcosmo que unifica em si todos os reinos do mundo criado.

A formação (Bildung) é uma atividade que visa atualizar as potencialidades já contidas na pessoa. É um processo que ocorre do interior para o exterior. Forma-se bem quando todas as dimensões do ser humano, corporal, psíquica e espiritual são consideradas e orientadas, para que cheguem à sua plena realização. É necessário ainda considerar o núcleo, ou alma da alma, no qual existe a originalidade individual de cada um. Edith Stein critica uma prática educativa que vise apenas um saber enciclopédico, um acúmulo de informações que privilegia unicamente a dimensão intelectual e menospreza as demais. Podemos afirmar que Stein visava uma formação integral e não uma pseudoformação.

Ainda que todas as dimensões sejam consideradas e devam ser formadas, Stein considera que a dimensão espiritual, constituída pela inteligência, razão e vontade deve reger o processo formativo. Em contato com o mundo dos valores e na vida em comunidade as potências existentes na alma humana podem ser ativadas, e por meio de atos livres e responsáveis a pessoa caminha para a plena realização de si mesma. Essa plena realização repercute na vida comunitária, de modo que cada pessoa que se forma assim contribui para o bem comum.

A liberdade que deve reger o ato educativo, não pode ser jamais esquecida no campo do Ensino Religioso. Qualquer forma de imposição, constrangimento ou censura de qualquer denominação religiosa sobre às demais depõe contra si mesma e, ao invés de favorecer a abertura ao Sagrado, à transcendência, contribui para seu fechamento.

Edith Stein rompe ainda, apoiada em Agostinho e Tomás de Aquino, com a ideia de uma ciência sem Deus. Reivindica uma metafísica cristã como aporte necessário para a compreensão do ser humano e para uma verdadeira reforma educacional, sobretudo da educação católica.

A autora acredita que existe uma verdade acerca de Deus e acerca do homem. E que só em relação a Deus se concebe a verdadeira dignidade humana. A origem, portanto, da dignidade humana é ontológica e teológica. Toda ciência humana que vê a Deus e o mistério 
encerrado em cada ser humano como uma ameaça, corre o risco de construir caricaturas a respeito da pessoa humana.

O ser humano não cabe em nossos esquemas, pois sempre os supera, sempre os subverte, sempre os transcende, pois sua essência comporta o infinito. Para compreender o ser humano somos o tempo todo convidados a ampliar o olhar, pois constantemente corremos o risco de estreitar nossa visão e passamos a enxergar o que convém.

Podemos nos questionar a quem interessa uma prática educativa que leve em consideração os princípios almejados por Edith Stein, ou que consequências decorrem desses princípios. Quem sabe da dignidade que possui não se curva diante da opressão alheia. Não se vende por interesses arbitrários. Quem reconhece o outro como semelhante não se cala diante das injustiças, dos abusos, da instrumentalização da vida por questões econômicas, políticas ou qualquer outro que negue a sacralidade de cada pessoa humana.

A visão católica do ser humano e seu ideal formativo não é a única, mas é uma visão que pode e deve ser considerada, ainda nos dias atuais, e não completamente superada, como sustentam alguns. Todo o esforço em marginalizar, depreciar e menosprezar tal visão vem, em parte, de uma ideia distorcida e fragmentada, mas também de uma tentativa de imposição de uma visão única, que não reconhece como científico o que não pode ser mensurado, manipulado, controlado. Uma visão materialista, em que espacialidade e exterioridade são imprescindíveis. Dessa visão chega-se facilmente a um humanismo imanentista, em que o homem torna-se o referencial absoluto.

Para Stein, o cristianismo não é um conjunto de preceitos e ideias a serem aprendidos e discutidos como um conjunto teórico. Ele é revolucionário, à medida em que pessoas humanas o assumam no cotidiano de suas vidas e se deixem formar e conduzir por eles. $\mathrm{O}$ dualismo religioso é uma das chagas do cristianismo, que faz com que alguns cristãos se satisfaçam em crer de uma forma e viver de outra. Edith Stein denunciava essa inconsistência e vem ser uma referência, um testemunho de alguém que não perdeu o sentido de uma religiosidade autêntica. 


\section{BIBLIOGRAFIA}

A. A. SBERGA e M. MASSIMI. A formação da pessoa em Edith Stein: contribuição para a construção de itinerários educativos para crianças, adolescentes e jovens. (Tese). Doutorado em Psicologia. Universidade de São Paulo, Ribeirão Preto, 2013.

A. M. PEZZELA, Lineamenti di filosofia dell'educazione- per una prospettiva fenomenologica dell'evento educativo, Lateran University Press, Vaticano, 2007.

BRASIL, LDB. Lei 9394/96 - Lei de Diretrizes e Bases da Educação Nacional. Disponível em: < www.planalto.gov.br $>$. Acesso em:10 nov 2017.

CATECISMO DA IGREJA CATÓLICA, 4.ed, Vozes, Petrópolos, 1993.

E. STEIN, La strutura della persona humana. Tradução de M. D’Ambra. Città Nuova, Roma, 2000. Título original: Der Aufbau der menschlichen Person, original publicado em 1932/33)

, Sobre el concepto de formaciòn. In STEIN, E... Obras completas IV: escritos antropológicos y pedagógicos. Tradução de F.J. Sancho e cols., Monte Carmelo, Espanha, 2003a, p. 177-194. (Publicação original de 1930).

, A mulher: Sua missão segundo a natureza e a graça. Tradução Alfred J. Keller. EDUSC, Bauru, 1999.

JOÃO PAULO II. Carta Encíclica Fides et ratio. 9 ed, Paulinas, São Paulo, 2006, p. 99. 